\title{
One-Pot-Multicomponent Synthesis of 2,6-Diamino-4-arylpyridine-3,5-dicarbonitrile Derivatives Using Nanomagnetic $\mathrm{Fe}_{3} \mathrm{O}_{4} @ \mathrm{SiO}_{2} @ \mathrm{ZnCl}_{2}$
}

\author{
Behrooz Maleki ${ }^{1, \star}$, Hadi Natheghi ${ }^{1}$, Vahid Sokhanvaran ${ }^{2}$, and Samaneh Sedigh Ashrafi ${ }^{1}$ \\ ${ }^{1}$ Department of Chemistry, Faculty of Sciences, Hakim Sabzevari University, Sabzevar 96179-76487, Iran \\ ${ }^{2}$ Faculty of Basic Sciences, University of Neyshabur, Neyshabur, Iran
}

Received February 4, 2018; Accepted July 24, 2018

\begin{abstract}
NanomagneticFe $\mathrm{O}_{3} @ \mathrm{SiO}_{2} @ \mathrm{ZnCl}_{2}$ was used as a simple, cost-effective, and reusable heterogeneous catalyst for the synthesis of 2,6-diamino-4-arylpyridine-3,5-dicarbonitriles by a one-pot-three-component condensation reaction of malononitrile, ammonium acetate, and aldehydes under solvent-free conditions at $110^{\circ} \mathrm{C}$. Simple and mild reaction conditions, facile preparation of the catalyst, the use of a cheap catalyst and easy workup and isolation are notable features of this method.
\end{abstract}

Keywords: 2,6-diamino-4-arylpyridine-3,5-dicarbonitriles; nano magnetic $\mathrm{Fe}_{3} \mathrm{O}_{4} @ \mathrm{SiO}_{2} @ \mathrm{ZnCl} 2$; green chemistry; multicomponent reaction

\section{ABSTRAK}

Nanomagnetik $\mathrm{Fe}_{3} \mathrm{O}_{4} @ \mathrm{SiO}_{2} @ \mathrm{ZnCl}_{2}$ digunakan sebagai katalis sederhana, hemat biaya, dan merupakan katalis heterogen yang dapat digunakan kembali untuk sintesis 2,6-diamino-4-arilpiridin-3,5-dikarbonitril melalui reaksi kondensasi tiga komponen one-pot antara malononitril, amonium asetat, dan aldehida dengan kondisi tanpa pelarut pada temperatur $110{ }^{\circ} \mathrm{C}$. Kondisi reaksi yang sederhana dan ringan, persiapan katalis yang mudah, penggunaan katalis yang murah dan mudah dilakukan serta mudah diisolasi adalah aspek yang penting dari metode ini.

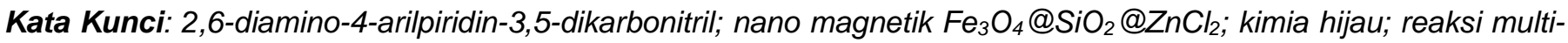
komponen

\section{INTRODUCTION}

In recent years, magnetic nanoparticles (MNPs), have proven to be valuable assets in organic chemistry. In this field of research, several studies have been carried out on their biological and technological applications such as drug delivery [1-2], magnetic resonance imaging (MRI) [3], bioseparation [4-5] bimolecular sensors [6-7] and magneto-thermal therapy [8-9]. Recent reports show that magnetic nanoparticles are efficient supports which can facilitate the isolation and recycling of expensive catalysts from the reaction media [10-12].

Construction of functionalized $N$-heterocycles utilizing Multicomponent reaction (MCR) strategy has evolved as a new synthetic tool [13-15]. $\mathrm{N}$-containing heterocycles show a vast abundance of numerous natural products and several biologically active pharmaceuticals. Among the all heteroaromatic compounds, polysubstituted pyridines are unrivaled and also considered as "privileged medicinal scaffolds" because they are partial structures of many natural products, pharmaceuticals, and synthetic organic moieties [16-21].

* Corresponding author. Tel : +98-51-4002643

Email address : b.maleki@hsu.ac.ir
Recently, pyridine-3,5-dicarbonitriles have displayed several applications in medicinal fields. 2,6Diamino-4-arylpyridine-3,5-dicarbonitrile derivatives present cytotoxic properties against A-549, P-388, HT29 , and MEL-28 tumoral cell lines, the capability of very potent inhibitors of histamine release [22]. Their applications as electrical materials [23], nonlinear optical materials [24], fluorescent liquid crystals [25], and chelating agents in metal-ligand chemistry [26] are considered very important. On the other hand, the 2aminopyridine structural motif exists in several significant biologically active compounds [27-30].

Preparation of 2,6-diamino-4-arylpyridine-3,5dicarbonitriles can be carried out by multicomponent reaction of aldehydes, malononitrile, and amines or ammonia [31-35] such as the reaction of amines with a 6-chloro substituent of 2-amino-4-phenyl-pyridine-3,5dicarbonitrile [36-37], usage of 3-amino-3-ethoxyacrylo nitrile (ethyl 2-cyanoacetimidate) [38-39] and (trimethoxy methyl)benzene [40]. Accordingly, discovery and development of an efficient process to obtain new derivatives of these compounds are still desirable for the

DOI: 10.22146/ijc.33062 
purposes of drug discovery. However, some of these catalysts suffer from the drawbacks of the perspective of green chemistry such as prolonged reaction times, toxic and corrosive solvent, non-reusable catalyst, unsatisfactory yields, expensive catalysts, and the need to use the microwave or ultrasonic irradiation in some cases. Therefore, it seemed desirable to develop greener and milder methods for the 2,6-diamino-4-arylpyridine3,5-carbonitrile. Green chemistry approaches are most important due to the reduction in byproducts, a reduction in produced waste, and reduction of energy cost [41-48].

With these precedents in mind, along with the understanding of the $4 \mathrm{H}$-thiopyrans formation mechanism through 2-arylpropane-1,1,3,3-tetracarbonitrile intermediates [49], we report the one-pot multicomponent synthesis of 2,6-diamino-3,5-dicarbonitrile pyridine derivatives from reactions of aldehydes (1), malononitrile (2), and ammonium acetate (3) using nanomagnetic $\mathrm{Fe}_{3} \mathrm{O}_{4} @ \mathrm{SiO}_{2} @ \mathrm{ZnCl}_{2}$ as a catalyst under solvent-free conditions.

\section{EXPERIMENTAL SECTION}

\section{Materials}

Chemicals (malononitrile, aldehydes, ammonium acetate, $\mathrm{FeCl}_{3} .6 \mathrm{H}_{2} \mathrm{O}, \quad \mathrm{FeCl}_{2} .4 \mathrm{H}_{2} \mathrm{O}, \mathrm{NH}_{3}$, tetraethyl orthosilicate, $\mathrm{ZnCl}_{2}$, and ethanol) were purchased from Fluka, Merck, and Sigma-Aldrich chemical companies.

\section{Instrumentation}

IR spectra were recorded on a Shimadzu 435-U-04 spectrophotometer ( $\mathrm{KBr}$ pellets). ${ }^{1} \mathrm{H}$ NMR spectra were obtained using a Bruker $300 \mathrm{MHz}$ spectrometer in DMSO$\mathrm{d}_{6}$ using TMS as an internal reference. Melting points were determined in open capillary tubes in a Stuart BI Brønstead Electrothermal Cat No: IA9200 apparatus and are uncorrected.

\section{Procedure}

\section{General procedure for the preparation of 2,6-diamino- 4-arylpyridine-3,5-dicarbonitriles (4a-k)}

First, a mixture of aldehyde ( $1 \mathrm{mmol})$, ammonium acetate $(3 \mathrm{mmol})$ with malononitrile $(1.5 \mathrm{mmol})$, and nanomagnetic $\mathrm{Fe}_{3} \mathrm{O}_{4} @ \mathrm{SiO}_{2} @ \mathrm{ZnCl}_{2}(0.04 \mathrm{~g})$ was stirred magnetically under solvent-free for an appropriate time as mentioned in Table 2. After completion of the reaction (monitored by TLC), the reaction mixture was diluted with hot ethanol $(96 \%, 3 \mathrm{~mL})$. Next, the nanomagnetic catalyst was separated from the reaction mixture by employing an external magnet. Then, the resulting crude product was poured into crushed ice and the solid product, which separated, was filtered. After that, the catalyst was dried in an oven at $70{ }^{\circ} \mathrm{C}$ for $6 \mathrm{~h}$. Recovered catalyst was reused in subsequent reactions. Finally, the solid product was recrystallized from ethanol $(96 \%, 5 \mathrm{~mL})$ to get pure $4 a-k$ derivatives.

\section{Spectroscopic data for representative compounds} 2,6-Diamino-4-phenylpyridine-3,5-dicarbonitrile (4a). Yellow solid; m.p. $>300{ }^{\circ} \mathrm{C}$; IR $\left(\mathrm{KBr}, v, \mathrm{~cm}^{-1}\right)$ : 3475 , $3425,3363,3220,3158,2205,1674,1624,1586,1558$, 1540, 1458, 760; ${ }^{1 H} \mathrm{H}-\mathrm{NMR}(400 \mathrm{MHz}$, DMSO-d6) $\delta: 7.55-$ $7.54(\mathrm{~m}, 3 \mathrm{H}), 7.48-7.47(\mathrm{~m}, 2 \mathrm{H}), 7.27(\mathrm{~s}, 4 \mathrm{H}) \mathrm{ppm} ;{ }^{13} \mathrm{C}-$ $\operatorname{NMR}(100 \mathrm{MHz}, \mathrm{DMSO}-\mathrm{d} 6), \delta=165,161,128.6,128.3$, $138,116,5,111.4,79.8 \mathrm{ppm}$.

2,6-Diamino-4-(4-chlorophenyl)pyridine-3,5-dicarbo nitrile (4c). White solid; m.p. $>300^{\circ} \mathrm{C}$; IR $\left(\mathrm{KBr}, v, \mathrm{~cm}^{-1}\right)$ : $3478,3419,3364,3173,2209,1622,1573,1558,1541$, 1453, 1313, 1035, 764; ${ }^{1} \mathrm{H}-\mathrm{NMR}$ (400 MHz, DMSO-d6) $\delta$ : $7.65(\mathrm{~m}, 1 \mathrm{H}), 7.55-7.47(\mathrm{~m}, 3 \mathrm{H}), 7.35(\mathrm{~m}, 4 \mathrm{H}) \mathrm{ppm}$; ${ }^{13} \mathrm{C}-\mathrm{NMR}(100 \mathrm{MHz}$, DMSO-d6), $\delta=165,160,138.9$, $132.1,131.4,130.1,129.72,127.7,115.7,80.4$ ppm.

2,6-Diamino-4-(4-hydroxyphenyl)pyridine-3,5-dicarbo nitrile (4d). White solid; m.p. $>300^{\circ} \mathrm{C}$; IR $\left(\mathrm{KBr}, v, \mathrm{~cm}^{-1}\right)$ : 3416, 3368, 3166, 2205, 1626, 1565, 1539, 1302, 1173, 841; ' ${ }^{1} \mathrm{H}-\mathrm{NMR}(400 \mathrm{MHz}$, DMSO-d6) $\delta: 9.97(\mathrm{~s}, 1 \mathrm{H})$, 7.33-7.30 (m, 2H), $7.19(\mathrm{~m}, 4 \mathrm{H}), 6.90-6.88(\mathrm{~m}, 2 \mathrm{H}) \mathrm{ppm}$; ${ }^{13} \mathrm{C}-\mathrm{NMR}(100 \mathrm{MHz}, \mathrm{DMSO}-d 6), \delta=161.6,160.2,159.4$, $130.4,125.9,117.3,115.7,80.1 \mathrm{ppm}$.

\section{RESULT AND DISCUSSION}

In continuation of our efforts to develop new green chemistry methods as well as our interest in applications of heterogeneous-catalyzed organic reactions [50-56], we designed a simple and facile synthesis of $4 a-k$ by a three-component condensation reaction of aromatic aldehydes (1), malononitrile (2), and ammonium acetate (3), and under solvent-free conditions in the presence of nanomagnetic $\mathrm{Fe}_{3} \mathrm{O}_{4} @ \mathrm{SiO}_{2} @ \mathrm{ZnCl}_{2}$ as a core-shell and heterogeneous reusable nanocatalyst (Fig. 1). Because nanoparticle materials have enormously large and highly reactive surface area, they exhibit unique properties in comparison to bulk materials. For our investigations, nanomagnetic $\mathrm{Fe}_{3} \mathrm{O}_{4} @ \mathrm{SiO}_{2} @ \mathrm{ZnCl}_{2}$ was prepared according to the literature procedure [57].

To optimize the reaction conditions, the condensation reaction of ammonium acetate $(3 \mathrm{mmol})$, benzaldehyde $(1 \mathrm{mmol})$ and malononitrile $(1.5 \mathrm{mmol})$ were chosen, and different amounts of $\mathrm{Fe}_{3} \mathrm{O}_{4} @ \mathrm{SiO}_{2} @ \mathrm{ZnCl}_{2}$ as a heterogeneous catalyst in the range room temperature to $120^{\circ} \mathrm{C}$ were examined under solvent-free conditions (Table 1). As showed in Table 1, the best results were achieved when the reaction was done in the presence of $0.04 \mathrm{~g}$ of the catalyst at $110^{\circ} \mathrm{C}$ (Table 1, entry 1). No improvement was seen in the yield 
Table 1. Effect of temperature and amount catalyst on the synthesis of $4 \mathrm{a}$

\begin{tabular}{ccccc}
\hline Entry & $\begin{array}{c}\mathrm{Fe}_{3} \mathrm{O}_{4} @ \mathrm{SiO}_{2} @ \mathrm{ZnCl}_{2} \\
(\mathrm{~g})\end{array}$ & $\begin{array}{c}\mathrm{Temp} . \\
\left({ }^{\circ} \mathrm{C}\right)\end{array}$ & $\begin{array}{c}\text { Time } \\
(\mathrm{min})\end{array}$ & $\begin{array}{c}\text { Yield } \\
(\%)\end{array}$ \\
\hline 1 & 0.04 & 110 & 120 & 86 \\
2 & 0.04 & 100 & 120 & 80 \\
3 & 0.04 & 120 & 120 & 87 \\
4 & 0.03 & 110 & 120 & 82 \\
6 & 0.05 & 110 & 120 & 87 \\
7 & 0.04 & $\mathrm{rt}$ & 120 & Trace \\
8 & $-\mathrm{a}$ & 100 & 120 & 46 \\
\hline
\end{tabular}

an absence of a catalyst

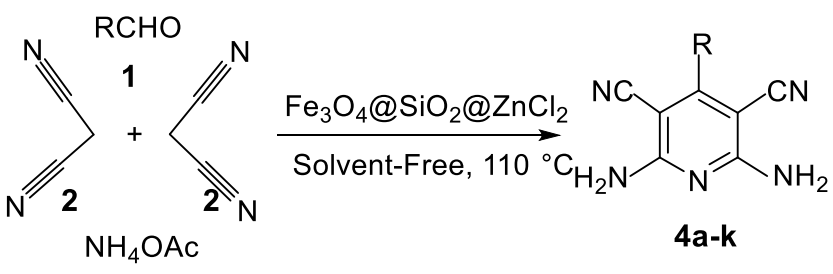

3

Fig 1. Synthesis of 2,6-diamino-4-arylpyridine-3,5dicarbonitriles (4a-k) using nanomagnetic $\mathrm{Fe}_{3} \mathrm{O}_{4} @ \mathrm{SiO}_{2}$ $@ \mathrm{ZnCl}_{2}$

Table 2. One-pot synthesis of 4a-k derivatives using nanomagnetic $\mathrm{Fe}_{3} \mathrm{O}_{4} @ \mathrm{SiO}_{2} @ \mathrm{ZnCl}_{2}$

Entry


Table 2. Continued

\begin{tabular}{|c|c|c|c|c|}
\hline Entry & Products $(4 a-k)^{a}$ & Time (min) & Yield (\%) & $\mathrm{Mp}^{\circ} \mathrm{C}$ (Lit.) \\
\hline $4 i$ & & 150 & 85 & $>300^{33}$ \\
\hline $4 j$ & & 120 & 82 & $>300^{33}$ \\
\hline $4 \mathrm{k}$ & & 160 & 86 & $>300^{33}$ \\
\hline
\end{tabular}

${ }^{a}$ All known products have been reported previously in the literature and were characterized by comparison of IR and NMR spectra with authentic samples.
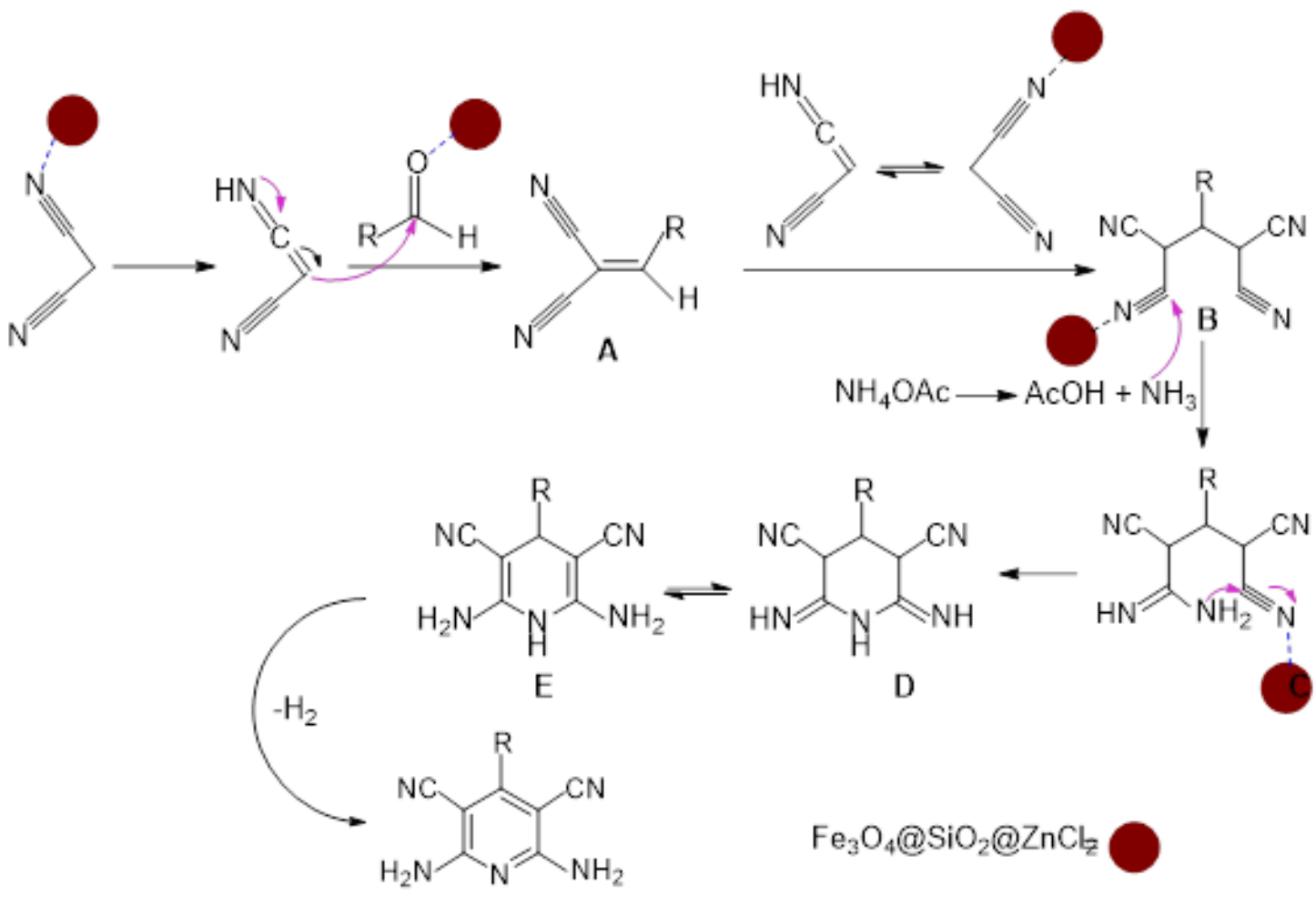

$4 \mathrm{a}-\mathrm{k}$

Fig 2. The proposed mechanism for the synthesis of 2,6-diamino-4-arylpyridine-3,5-dicarbonitrile (4a-k)

by increasing the amount of catalyst and temperature (Table 1, entries 6 and 3).

To investigate the efficacy and the generality of the catalyst, different aldehydes were reacted with ammonium acetate and malononitrile under the optimized reaction conditions. The results are presented in Table 2. All reactions proceeded efficiently to give $4 a-k$ in high yields and in short reaction times. The structures of the products were established from their spectral properties $\left({ }^{1} \mathrm{H}-\mathrm{NMR},{ }^{13} \mathrm{C}-\mathrm{NMR}\right.$, and elemental analysis) and also by comparison with available literature data (see experimental section).

The formation of 2,6-diamino-4-arylpyridine-3,5dicarbonitriles could be explained by a proposed tentative mechanism (Fig. 2). Our proposed mechanism for the one-pot-three-components synthesis of 2,6diamino-4-arylpyridine-3,5-dicarbonitriles in the presence of nanomagnetic $\mathrm{Fe}_{3} \mathrm{O}_{4} @ \mathrm{SiO}_{2} @ \mathrm{ZnCl}_{2}$ consists 


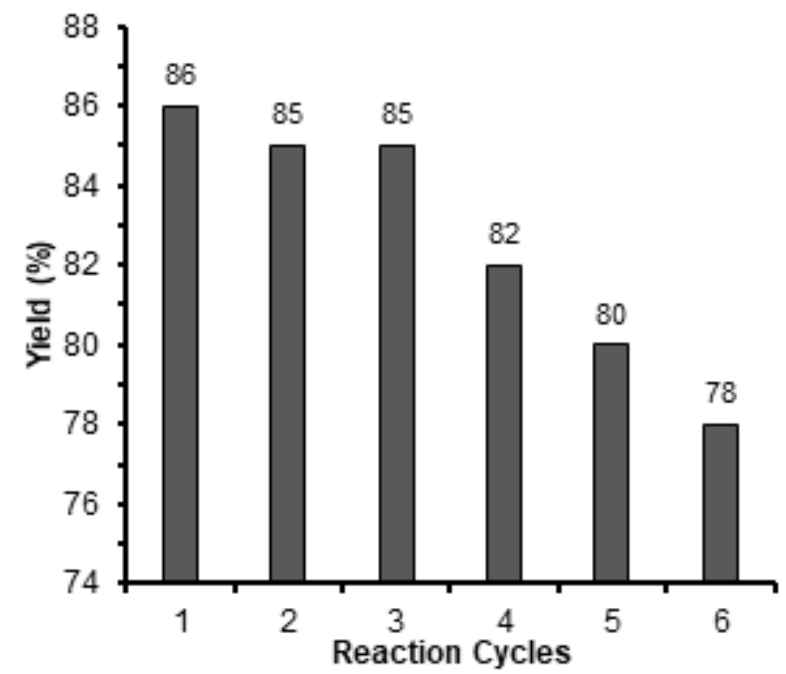

Fig 3. Reusability of nanomagnetic $\mathrm{Fe}_{3} \mathrm{O}_{4} @ \mathrm{SiO}_{2} @ \mathrm{ZnCl}_{2}$ for the model reaction

of the standard Knoevenagel condensation of aldehyde and malononitrile in the presence of nanomagnetic $\mathrm{Fe}_{3} \mathrm{O}_{4} @ \mathrm{SiO}_{2} @ \mathrm{ZnCl}_{2}$, which would lead to the formation of arylidene-malononitrile $\mathrm{A}$ as an intermediate. Michaeltype addition of the malononitrile 2 would provide the adduct B. Then, a nucleophilic attack of ammonium acetate on a cyanide group of $B$ gives the intermediate $C$. The structure $D$ that is in equilibration with $E$ tautomer would be produced by cycloaddition of C. Consequently, dehydrogenation to yield the product $4 \mathrm{a}-\mathrm{k}$ would be undergone by this tautomer.

The lifetime of the catalyst and its level of reusability are important factors in practical applications of heterogeneous systems. To simplify this issue, we established a set of experiments using the recycled catalyst for the synthesis of $4 a$. After the completion of the reaction, the catalyst was dried at $70^{\circ} \mathrm{C}$ for $6 \mathrm{~h}$. As shown in Fig. 3, the recovered catalyst was re-used six times to afford $86,85,85,82,80$ and $78 \%$ yields for $120 \mathrm{~min}$, respectively, without significant loss of its activity. In addition, the weight of the recovered catalyst is the same as the amount of the fresh catalyst used the first time in the reaction.

\section{CONCLUSION}

In conclusion, an efficient protocol for the one-pot synthesis of $4 a-k$ derivatives has been described under thermal solvent-free conditions using inexpensive starting materials. To the best of our knowledge, this new procedure represents the first example of a heterogeneous and reusable nanomagnetic $\mathrm{Fe}_{30}{ }_{4} @ \mathrm{SiO}_{2} @ \mathrm{ZnCl}_{2}$ catalyst for these three-component reactions.

\section{ACKNOWLEDGEMENT}

The authors thank the Research Council of Hakim Sabzevari University and the University of Neyshabur for partial support of this work.

\section{REFERENCES}

[1] Gupta, A.K., and Curtis, A.S.G., 2004, Surface modified superparamagnetic nanoparticles for drug delivery: Interaction studies with human fibroblasts in culture, J. Mater. Sci. - Mater. Med., 15 (4), 493496.

[2] Neuberger, T., Schöpf, B., Hofmann, H., Hofmann, M., and von Rechenberg, B., 2005, Superparamagnetic nanoparticles for biomedical applications: Possibilities and limitations of a new drug delivery system, J. Magn. Magn. Mater., 293 (1), 483-496.

[3] Pankhurst, Q.A., Connolly, J., Jones, S.K., and Dobson, J., 2003, Applications of magnetic nanoparticles in biomedicine, J. Phys. D: Appl. Phys., 36 (13), 167-181.

[4] Wang, D., He, J., Rosenzweig, N., and Rosenzweig, Z., 2004, Superparamagnetic $\mathrm{Fe}_{2} \mathrm{O}_{3}$ beads-CdSe/ZnS quantum dots core-shell nanocomposite particles for cell separation, Nano Lett., 4 (3), 409-413.

[5] Xu, C., Xu, K., Gu, H., Zheng, R., Liu, H., Zhang, X., Guo, Z., and Xu, B., 2004, Dopamine as a robust anchor to immobilize functional molecules on the iron oxide shell of magnetic nanoparticles, J. Am. Chem. Soc., 126 (32), 9938-9939.

[6] Perez, J.M., Simeone, F.J., Saeki, Y., Josephson, L., and Weissleder, R., 2003, Viral-induced selfassembly of magnetic nanoparticles allows the detection of viral particles in biological media, $J$. Am. Chem. Soc., 125 (34), 10192-10193.

[7] Graham, D.L., Ferreira, H.A., and Freitas, P.P., 2004, Magnetoresistive-based biosensors and biochips, Trends Biotechnol., 22 (9), 455-462.

[8] Hiergeist, R., Andra, W., Buske, N., Hergt, R., Hilger, I., Richter, U., and Kaiser, W., 1999, Application of magnetite ferrofluids for hyperthermia, J. Magn. Magn. Mater., 201 (1-3), 420-422.

[9] Jordan, A., Scholz, R., Wust, P., Fähling, H., and Felix, R., 1999, Magnetic fluid hyperthermia (MFH): Cancer treatment with $A C$ magnetic field induced excitation of biocompatible superparamagnetic nanoparticles, J. Magn. Magn. Mater., 201 (1-3), 413-419.

[10] Shokouhimehr, M., Piao, Y., Kim, J., Jang, Y., and Hyeon, T., 2007, A magnetically recyclable 
nanocomposite catalyst for olefin epoxidation, Angew. Chem. Int. Ed., 46 (37), 7039-7043.

[11] Tayebee, R., Amini, M.M., Abdollahi, N., Aliakbari, A., Rabiee, S., and Ramshini, H., 2013, Magnetic inorganic-organic hybrid nanomaterial for the catalytic preparation of bis(indolyl)arylmethanes under solvent-free conditions: preparation and characterization of $\mathrm{H}_{5} \mathrm{PW}_{10} \mathrm{~V}_{2} \mathrm{O}_{40}$ /pyridino- $\mathrm{Fe}_{3} \mathrm{O}_{4}$ nanoparticles, Appl. Catal., A, 468 (5), 75-87.

[12] Rahmayeni, R., Arief, S., Stiadi, Y., Rizal, R., and Zulhadji, Z., 2012, Synthesis of magnetic nanoparticles of $\mathrm{TiO}_{2}-\mathrm{NiFe}_{2} \mathrm{O}_{4}$ : Characterization and photocatalytic activity on degradation of rhodamine B, Indones. J. Chem., 12 (3), 229-234.

[13] Reddy, L.S., Reddy, T.R., Mohan, R.B., Mahesh, A., Lingappa, Y., and Reddy, N.C.G., 2013, An efficient green multi-component reaction strategy for the synthesis of highly functionalized pyridines and evaluation of their antibacterial activities, Chem. Pharm. Bull., 61 (11), 1114-1120.

[14] Kankala, S., Pagadala, R., Maddila, S., Vasam, C.S., and Jonnalagadda, S.B., 2015, Silver(I)-Nheterocyclic carbene catalyzed multicomponent reactions: A facile synthesis of multisubstituted pyridines, RSC Adv., 5 (127), 105446-105452.

[15] Khalili, D., 2016, Graphene oxide: A reusable and metal-free carbocatalyst for the one-pot synthesis of 2-amino-3-cyanopyridines in water, Tetrahedron Lett., 57 (15), 1721-1723.

[16] Katritzky, A.R., Rees, C.W., and Scriven, E.F.V., 1996, Comprehensive Heterocyclic Chemistry II, $2^{\text {nd }}$ ed., Pergamon, Oxford, UK.

[17] Gribble, G.W., and Joule, J., 2009, Progress in Heterocyclic Chemistry, vol. 21, Elsevier Science, New York.

[18] Rao, A.V.R., Reddy, G.R., and Rao, B.V., 1991, Stereoselective synthesis of theonelladins A-D, J. Org. Chem., 56 (14), 4545-4547.

[19] Jayasinghe, L., Jayasooriya, C.P., Hara, N., and Fujimoto, Y., 2003, A pyridine ring-containing ecdysteroid from Diploclisia glaucescens, Tetrahedron Lett., 44 (49), 8769-8771.

[20] Kubota, T., Nishi, T., Fukushi, E., Kawabata, J., Fromont, J., and Kobayashi, J., 2007, Nakinadine A, a novel bis-pyridine alkaloid with a $\beta$-amino acid moiety from sponge Amphimedon sp, Tetrahedron Lett., 48 (29), 4983-4985.

[21] Brian, P.M., and Musau, P., 2016, Synthesis, reactivity and stability of aryl halide protecting groups towards di-substituted pyridines, Indones. J. Chem., 16 (1), 53-58.

[22] Quintela, J., Peinador, C., Botana, L., Estevez, M., and Riguera, R., 1997, Synthesis and antihistaminic activity of 2-guanadino-3-cyanopyridines and pyrido[2,3- $d$-pyrimidines, Bioorg. Med. Chem., 5 (8), 1543-1553.

[23] Kanbara, T., Kushida, T., Saito, N., Kuwajima, I., Kubota, K., and Yamamoto, T., 1992, Preparation, and properties of highly electron-accepting poly(pyrimidine-2,5-diyl), Chem. Lett., 21 (4), 583586.

[24] Wang, H., Helgeson, R., Ma, B., and Wudl, F., 2000 , Synthesis and optical properties of crossconjugated bis(dimethylaminophenyl)pyridylviny lene derivatives, J. Org. Chem., 65 (18), 58625867.

[25] Petrov, V.F., Pavluchenko, A.I., and_Smirnova, N.I., 1995, New liquid crystalline pyridine derivatives, Mol. Cryst. Liq. Cryst. Sci. Technol., Sect. A, 265 (1), 47-53.

[26] Meyer, T.J., 1989, Chemical approaches to artificial photosynthesis, Acc. Chem. Res., 22 (5), 163-170.

[27] Cocco, M.T., Congiu, C., Lilliu, V., and Onnis, V., 2007, Synthesis and in vitro antitumoral activity of new 3,5-dicyanopyridine derivatives, Bioorg. Med. Chem., 15 (4), 1859-1867.

[28] Cocco, M.T., Congiu, C., Lilliu, V., and Onnis, V., 2005 , Synthesis and antiproliferative activity of 2, 6dibenzylamino-3, 5-dicyanopyridines on human cancer cell lines, Eur. J. Med. Chem., 40 (12), 1365-1372.

[29] Zhou, D., Lee, H., Rothfuss, J.M., Chen, D.L., Ponde, D.E., Welch, M.J., and Mach, R.H., 2009, Design and synthesis of 2-amino-4-methylpyridine analogues as inhibitors for inducible nitric oxide synthase and in vivo evaluation of $\left[{ }^{18} \mathrm{~F}\right] 6-(2-$ fluoropropyl)-4-methyl-pyridin-2-amine as a potential PET Tracer for Inducible nitric oxide synthase, J. Med. Chem., 52 (8), 2443-2453.

[30] Scott, N.M., Schareina, T., Tok, O., and Kempe, R., 2004, Lithium and potassium amides of sterically demanding aminopyridines, Eur. J. Inorg. Chem., 2004 (16), 3297-3304.

[31] Sarkar, S., Das, D.K., and Khan, A.T., 2014, Synthesis of fully-substituted pyridines and dihydropyridines in a highly chemoselective manner utilizing a multicomponent reaction (MCR) strategy, RSC Adv., 4 (96), 53752-53760.

[32] Raghukumar, V., Thirumalai, D., Ramakrishnan, V.T., Karunakara, V., and Ramamurthy, P., 2003, Synthesis of nicotinonitrile derivatives as a new class of NLO materials, Tetrahedron, 59 (21), 3761-3768.

[33] Huang, J., Zhou, J., Song, S., Song, H., Chen, Z., and $\mathrm{Yi}, \mathrm{W} ., 2015, \mathrm{~A}$ new and efficient $\mathrm{ZnCl}_{2}-$ catalyzed synthesis and biological evaluation of novel 2-amino-3,5-dicyano-4-aryl-6-arylaminopyridines as potent antibacterial agents 
against Helicobacter pylori (HP), Tetrahedron, 71 (45), 8628-8636.

[34] Yang, J., Li, J., Hao, P., Qiu, F., Liu, M., Zhang, Q., and Shi, D., 2015, Synthesis, optical properties of multi donor-acceptor substituted AIE pyridine derivatives dyes and application for $\mathrm{Au}^{3+}$ detection in aqueous solution, Dyes Pigm., 116, 97-105.

[35] Mobinikhaledi, A., Asadbegi, S., and Bodaghifard, M.A., 2016, Convenient, multicomponent, one-pot synthesis of highly substituted pyridines under solvent-free conditions, Synth. Commun., 46 (19), 1605-1611.

[36] Murray, T.J., Zimmerman, S.C., and Kolotuchin, S.V., 1995, Synthesis of heterocyclic compounds containing three contiguous hydrogen bonding sites in all possible arrangements, Tetrahedron, 51 (2), 635-648.

[37] Samadi, A., Silva, D., Chioua, M., Carreiras, M.C., and Marco-Contelles, J., 2011, Microwave irradiation-assisted amination of 2-chloropyridine derivatives with amide solvents, Synth. Commun., 41 (19), 2859-2869.

[38] Harada, H., Watanuki, S., Takuwa, T., Kawaguchi, K., Okazaki, T., Hirano, Y., and Saitoh, C., 2003, Medicine comprising dicyanopyridine derivative, US20030232860A1.

[39] Mashaly, M.M., and Hammoudab, M., 1999, New simple and one-pot synthetic routes to polyfunctionally substituted pyridines; 1,4-dihydropy ridazines and 4H-1,2-oxazine, $Z$. Naturforsch., $B$ : Chem. Sci., 54 (9), 1205-1209.

[40] Maleki, B., Rezaei-Seresht, E., and Ebrahimi, Z., 2015, Friedlander synthesis of quinolines promoted by polymer-bound sulfonic acid, Org. Prep. Proced. Int., 47 (2), 149-160.

[41] Maleki, B., 2015, Solvent-free synthesis of 2,4,6triarylpyridine derivatives promoted by 1,3-dibromo5,5-dimethylhydantoin, Org. Prep. Proced. Int., 47 (2), 173-178.

[42] Maleki, B., Zonoz, F.M., and Akhlaghi, H.A., 2015, An efficient synthesis of symmetrical $N, N^{\prime}$-alkylidene bisamides catalyzed by a heteropolyacid, Org. Prep. Proced. Int., 47 (5), 361-367.

[43] Maleki, B., Kahoo, G.E., and Tayebee, R., 2015, One-pot synthesis of polysubstituted imidazoles catalyzed by an ionic liquid, Org. Prep. Proced. Int., 47 (6), 461-472.

[44] Maleki, B., Raei, M., Alinezhad, H., Tayebee, R., and Sedrpoushan, A., 2018, Chemoselective synthesis of tetraketones in water catalyzed by nanostructured diphosphate $\mathrm{Na}_{2} \mathrm{CaP}_{2} \mathrm{O}_{7}$, Org. Prep. Proced. Int., 50 (3), 288-300.

[45] Ren, Y.M., Shao, J.J., Wu, Z.C., and Xu, M.D., 2014, PEG1000-Based dicationic acidic ionic liquid catalyzed one-pot synthesis of 1,4-dihydropyridines via the Hantzsch reaction, Org. Prep. Proced. Int., 46 (6), 545-550.

[46] Mastitski, A., and Järv, J., 2014, One-pot synthesis of Fmoc-and Boc-protected aza-methionine precursors from 2-methylthioacetaldehyde dimethyl acetal, Org. Prep. Proced. Int., 46 (6), 559-564.

[47] Wang, M., Song, J.L., Zhao, S., and Wan, X., 2014, Synthesis of 3,4-dihydropyrimidin-2(1H)-ones using sodium bisulfate as a catalyst under solvent-free conditions, Org. Prep. Proced. Int., 46 (5), 457-462.

[48] Mobinikhaledi, A., Bodaghifard, M.A., and Asadbegi, S., 2016, A novel four- and pseudo-fivecomponent reaction: Unexpected efficient one-pot synthesis of $4 \mathrm{H}$-thiopyran derivatives, Mol. Diversity, 20 (2), 461-468.

[49] Maleki, B., Rooky, R., Rezaei-Seresht, E., and Tayebee, R., 2017, One-pot synthesis of bicyclic ortho-aminocarbonitrile and multisubstituted cyclohexa-1,3-dienamine derivatives, Org. Prep. Proced. Int., 49 (6), 557-567.

[50] Maleki, B., and Mofrad, A.V., 2017, Efficient synthesis of quinazoline derivatives catalyzed by flourinated alcohol, Res. Chem. Intermed., 43 (5), 3111-3120.

[51] Maleki, B., Eshghi, H., Barghamadi, M., Nasiri, N., Khojastehnezhad, A., Sedigh Ashrafi, S., and Pourshiani, O., 2016, Silica-coated magnetic $\mathrm{NiFe}_{2} \mathrm{O}_{4}$ nanoparticles-supported $\mathrm{H}_{3} \mathrm{PW}_{12} \mathrm{O}_{40}$; synthesis, preparation, and application as an efficient, magnetic, green catalyst for one-pot synthesis of tetrahydrobenzo[b]pyran and pyrano[2,3-c]pyrazole derivatives, Res. Chem. Intermed., 42 (4), 3071-3093.

[52] Maleki, B., Baghayeri, M., Sheikh, S., Babaee, S., and Farhadi, S.,2017, One-pot synthesis of some 2amino- $4 \mathrm{H}$-chromene derivatives using triethanolamine as a novel reusable organocatalyst under solvent-free conditions and its application in electrosynthesis of silver nanoparticles, Russ. J. Gen. Chem., 87 (87), 1064-1072.

[53] Veisi, H., Naeimi, A.R., Maleki, B., Sedigh Ashrafi, S., and Sedrpoushan, A.R., 2015, Synthesis of 5alkylidene-2, 4-thiazolidinediones and rhodanines promoted by propylamino-functionalized nanostructured SBA-15, Org. Prep. Proced. Int., 47 (4), 309-315.

[54] Maleki, B., 2016, One-Pot Synthesis of some 2amino-4H-benzo[g]chromenes, Org. Prep. Proced. Int., 48 (1), 81-87.

[55] Maleki, B., 2016, Green synthesis of bis-Coumarin and dihydropyrano[3,2-c]chromene derivatives catalyzed by 0 -benzenedisulfonimide, Org. Prep. Proced. Int., 48 (3), 303-318.

[56] Maleki, B., Akbarzadeh, E., and Babaee, S., 2015, New basic ionic liquid from ethan-1,2-diyl bis 
(hydrogen sulfate) and DBU (1,8-diazobicyclo[5.4.0] undec-7-ene) as an efficient catalyst for one-pot synthesis of xanthene derivatives, Dyes. Pigm., 123, 222-234.
[57] Soleimani, E., Namivandi, M.N., and Sepahvand, $\mathrm{H}$., 2017, $\mathrm{ZnCl}_{2}$ supported on $\mathrm{Fe}_{3} \mathrm{O}_{4} @ \mathrm{SiO}_{2}$ coreshell nanocatalyst for the synthesis of quinolines via Friedländer synthesis under solvent-free condition, Appl. Organomet. Chem., 31 (2), 3566-3574. 